\title{
Multiple Forms of Genetic Instability within a 2-Mb Chromosomal Segment of 3q26.3-q27 Are Associated with Development of Esophageal Adenocarcinoma
}

\author{
Lin Lin, ${ }^{*}$ Zhuwen Wang, ${ }^{\prime}$ Michael S. Prescott, ${ }^{1}$ Herman van Dekken, ${ }^{5}$ Dafydd G. Thomas, ${ }^{2}$ Thomas J. Giordano, ${ }^{2}$ \\ Andrew C. Chang, 'Mark B. Orringer, ${ }^{1}$ Stephen B. Gruber, ${ }^{3}$ John V. Moran, ${ }^{4}$ Thomas W. Glover, ${ }^{4}$ and David G. Beer ${ }^{\prime *}$ \\ 'Department of Surgery, University of Michigan, Ann Arbor, Michigan \\ ${ }^{2}$ Department of Pathology, University of Michigan, Ann Arbor, Michigan \\ ${ }^{3}$ Department of Internal Medicine, University of Michigan, Ann Arbor, Michigan \\ ${ }^{4}$ Department of Human Genetics, University of Michigan, Ann Arbor, Michigan \\ ${ }^{5}$ Department of Pathology, Erasmus Medical Center, University Medical Center Rotterdam, The Netherlands
}

Gene amplification is one of the mechanisms to activate oncogenes in many cancers, including esophageal adenocarcinoma (EA). In the present study, we used two-dimensional restriction landmark genome scanning to clone a Notl/Dpnll fragment that showed increased genomic dosage in I of 44 EAs analyzed. This fragment maps to $3 q 26.3-q 27$, and subsequent experiments identified two intrachromosomal amplicons within a 10-Mb DNA segment in 7 of 75 (9\%) EAs. The distal amplified-core region maps centromeric to the PIK3CA locus, and a microsatellite (D3SI754) within this region exhibited significant instability (MSI), in stark contrast to the genomewide microsatellite stability found in EA. D3SI754-MSI arises in premalignant Barrett's dysplastic cells and preceded amplification of the nascent MSI allele in the corresponding EA. Seven ESTs within the amplified-core were overexpressed in amplicon-containing EAs. One of these, EST AW5 13672, represents a chimeric transcript that initiated from an antisense promoter sequence in the $5^{\prime} U T R$ of a full-length LINE-I element (LI-5'ASP). Similar chimeric transcripts encoding portions of the MET oncogene and the BCAS3 gene also were overexpressed in EAs, suggesting that LI-5'ASP activation may occur at a broad level in primary EAs. Thus, the fine dissection of a 2-Mb amplified DNA segment in 3q26.3-q27 in EA revealed multiple genetic alterations that had occurred sequentially and/or concurrently during EA development. This article has supplementary material, available at http://www.interscience.wiley.com/jpages// 045-2257/suppmat. @ 2005 Wiley-Liss, Inc.

\section{INTRODUCTION}

The incidence of esophageal adenocarcinoma (EA) has been increasing rapidly in many western countries (Devesa et al., 1998; Bollschweiler et al., 2001). Chronic gastroesophageal reflux (GER) has been proposed as a major risk factor for the development of Barrett's metaplasia, and EA frequently is associated with adjacent Barrett's metaplasia and/or dysplasia (Winters et al., 1987; Lagergren et al., 1999). The prognosis for patients with EA is poor, with a 5-year survival rate of only $10 \%$ (Farrow and Vaughan, 1996).

A number of genetic alterations have been observed in EAs. These include the frequent occurrence of somatic mutations and/or loss of heterozygosity $(\mathrm{LOH})$ in the TP53 and CDKN2A tumor-suppressor genes in both EA and pre-malignant Barrett's mucosa (Casson et al., 1991; Barrett et al., 1996). In addition, the use of comparative genomic hybridization (CGH) has enabled observation of multiple genomic losses and/or gains in EA (Riegman et al., 2001). Through the use of two-dimensional restriction landmark genome scanning (2-D RLGS) and STS-amplification map- ping, we previously reported finding intrachromosomal amplicons at multiple chromosomal locations in EAs and identifying candidate genes that may be involved in cancer development and/or progression (Hughes et al., 1998; Lin et al., 2000a; 2000b; Lin et al., 2002; Miller et al., 2003a). Gene amplification represents one essential mechanism for the activation of proto-oncogenes and is a tumor-specific event that does not occur in the normal human genome (Bishop, 1987). Therefore, identifying and characterizing these amplicons are important to delineate the molecular events that underlie EA tumorigenesis.

In the present article, we report the identification of a 2-Mb intrachromosomal amplicon at

Supported by: NIH; Grant number: CA71606; Roy Weber Research Endowment.

* Correspondence to: Lin Lin or David G. Beer, Department of Surgery Thoracic Section, University of Michigan Medical School, B560 MSRB2, Box 0686, Ann Arbor, MI 48109.

E-mail: linlin@umich.edu ordgbeer@umich.edu

Received 16 June 2005; Accepted 17 October 2005

DOI 10.1002/gcc.20293

Published online 30 November 2005 in

Wiley InterScience (www.interscience.wiley.com). 
3q26.3-q27 in EAs. The amplified DNA fragment is associated with various forms of genomic instability, including regional microsatellite instability, overexpression of various cellular transcripts, and the induction of a chimeric transcript initiated from an antisense promoter located in the $5^{\prime} \mathrm{UTR}$ of a full-length LINE-1 element. The presence of these varied genetic alterations within a $2-\mathrm{Mb}$ chromosomal segment in EA may suggest a common mechanism in cancer development but will certainly require additional studies of this and other cancer types.

\section{MATERIALS AND METHODS}

\section{Tissue Collection}

Tumors and their associated normal tissue were obtained from patients undergoing esophagectomy or pulmonary resection at the University of Michigan Medical Center between 1992 and 2000. Patients provided written consent, and the project was approved by the University of Michigan Institutional Review Board. Patients in this study had no preoperative radiotherapy or chemotherapy. Tissue samples were frozen in liquid nitrogen and stored at $-80^{\circ} \mathrm{C}$ until use.

\section{Cell Lines}

Two cell lines, Flo-1 and Bic-1, were derived from EA tissues in our laboratory. Het-1A is a human esophageal squamous cell line immortalized using SV40 and was kindly provided by Dr. Gary Stoner of Ohio State University.

\section{DNA Isolation and 2-D RLGS Gel Electrophoresis}

High-molecular-weight DNA was isolated as previously described (Blin and Stafford, 1976). All tumor portions used for DNA isolation were more than $70 \%$ tumor cells, as determined by frozen-tissue sectioning. Two-dimensional RLGS gel electrophoresis was performed as previously described (Kuick et al., 1995).

\section{Cloning of 2-D DNA Fragment}

The 2-D DNA fragment was purified and cloned as previously described (Lin et al., 2000b). Individual colonies were collected for DNA isolation (minipreps) using QIAprep ${ }^{\circledR}$ Spin Miniprep kit (Qiagen, Valencia, CA).

\section{Bioinformatic Analysis}

The sequences of the cloned fragments were analyzed by NCBI BLAST tools (www.ncbi. nlm.nih.gov). Precise chromosome location of the cloned 2-D fragment was determined by analyzing the resulting BAC sequences using NCBI's bioinformatic tools, electronic PCR, and Map Viewer. Exon and gene prediction software, GrailEXP (grail.lsd.ornl.gov/grailexp/) and GENSCAN (genes.mit.edu/GENSCAN.html), was used in conjunction with the GenBank EST database to determine expressed sequences within selected contigs.

\section{Comparative Genomic Hybridization (CGH) and Interphase Fluorescence in situ Hybridization (FISH) Assays}

CGH analysis was performed as described previously (Riegman et al., 2001). DNA loss was defined as chromosomal regions in which the mean greento-red signal ratio was below 0.80 , whereas gain was defined as regions in which the ratio was above 1.20. High-level amplification was seen as a distinct peak (ratio $>1.5$ ). At least 8-10 metaphases were used per sample. Interphase FISH was assayed as described previously (Lin et al., 2002), except for the chromosome arm $14 \mathrm{q}$ probe (BAC clone R-35609 DNA), which was cohybridized as a control with the target probe BAC AC076966, which includes the amplified 2-D sequence.

\section{STS Amplification Mapping Using Quantitative Genomic PCR (QG-PCR)}

STS/EST/gene markers in the 3q26-q27 regions were selected for QG-PCR, as previously described (Lin et al., 2000a). QG-PCR is a semiquantitative PCR procedure that involves a multiplex PCR reaction in which a pair of primers from the control sequence, either $G A P D H$ or the same chromosome centromeric/telomeric markers, were coamplified with the target genomic sequence in the same PCR reaction. Densitometry of PCR product signal ratios (Ts/c:Ns/c) for tumor (Ts/c, tumor STS fragment/tumor control) and normal (Ns/c, normal STS fragment/normal control) DNA was quantified using ImageQuant software (Amersham Biosciences, Piscataway, NJ). When the paired normal was not informative, the other normal samples were compared with the tumor, and the ratio was calculated. Values $\geq 2.0$ were considered indicative of DNA amplification, and values between 1.5 and 1.9 were considered to indicate copy number gain. All assays were repeated three times.

\section{Microsatellite Instability Screening, MMR Gene Mutation, and Tissue Microarray Analyses}

Thirty microsatellite (MS) markers were chosen (Table 1) including the five recommended by the 
TABLE I. Microsatellite Markers Investigated

\begin{tabular}{|c|c|c|c|c|c|}
\hline Marker & $\begin{array}{c}\text { Chromosome } \\
\text { (map location in } \mathrm{Mb} \text { ) }\end{array}$ & Repeat type & Repeat nucleotide & $\begin{array}{l}\text { Repeat length } \\
\text { (bp) }\end{array}$ & $\operatorname{MSI}(n)$ \\
\hline$D 3 S / 754^{\mathrm{a}}$ & $3(178.8)$ & Tetrarepeat & $($ TAGA $) n$ & 98 & $12 / 76$ \\
\hline D2SII9 & $2(44.1)$ & Direpeat & $(\mathrm{CA}) n$ & 34 & $0 / 48$ \\
\hline Bat-26 ${ }^{\mathrm{b}, *}$ & $2(47.6)$ & Monorepeat & (A)n & 26 & $0 / 44$ \\
\hline D2SI23* & $2(5 \mid .3)$ & Direpeat & $(\mathrm{CA}) n$ & 60 & $0 / 44$ \\
\hline Bat-2 $I^{b}$ & $3(37.0)$ & Mono- + direpeats & $(\mathrm{A}) n+(\mathrm{TA}) n$ & $20+26$ & I/46 (L6I) \\
\hline D3S3603 & $3(181.2)$ & Direpeat & $(\mathrm{CA}) n$ & 56 & $0 / 12$ \\
\hline AFM072yb7 & $3(183.3)$ & Direpeat & $(\mathrm{CA}) n$ & 42 & $0 / 12$ \\
\hline D3S23/4 & $3(183.5)$ & Tetra- + trirepeats & $($ TAGA $) n+(\text { TTA })_{n}$ & $66+42$ & $0 / 12$ \\
\hline D3S3609 & $3(185.3)$ & Direpeat & $(\mathrm{CA}) n$ & 46 & $0 / 12$ \\
\hline$C l \_4 \_I$ & $6(31.4)$ & Tetrarepeat & $(\mathrm{CAAA}) n$ & 32 & $0 / 42$ \\
\hline DIOS23/4 & $10(2.2)$ & Tetrarepeat & $(\mathrm{TAGA}) n$ & 74 & $1 / 44\left(163^{\circ}\right)$ \\
\hline DIOS23/8 & $10(18.6)$ & Direpeat & $(\mathrm{CA}) n$ & 52 & $0 / 44$ \\
\hline DIOS $197^{*}$ & $10(46.8)$ & Direpeat & $(\mathrm{CA}) n$ & 50 & 2/44 (D66, T67") \\
\hline DIOS54I & 10 (89.7) & Direpeat & $(\mathrm{CA}) n$ & 56 & $0 / 48$ \\
\hline DIOS2309 & $10(91.8)$ & Tetra- + direpeats & $(\mathrm{TAAA}) n+(\mathrm{CA}) n$ & $48+26$ & $0 / 44$ \\
\hline DIOS23II & $10(92.4)$ & Tetrarepeat & $(T A G A) n$ & 140 & $2 / 75\left(\mathrm{FI} 2, \mathrm{~V} 65^{\circ}\right)$ \\
\hline DIOS2317 & $10(102.2)$ & Direpeat & $(\mathrm{CA}) n$ & 34 & 2/75 (D0I, W6I") \\
\hline$D / 0 S 23 / 2$ & $10(110.4)$ & Tetrarepeat & $($ TAGA)n & 88 & $0 / 44$ \\
\hline DIOS2310 & $10(113.6)$ & Tetrarepeat & $($ TTTA $n$ & 52 & I/44 (M59) \\
\hline DIIS904 & II (26.6) & Di- + Hexrepeats & $(\mathrm{CA}) n+($ TATATG $) n$ & $58+54$ & $0 / 48$ \\
\hline CTG-B37 & $12(6.9)$ & Trirepeat & $(\mathrm{CAG}) n$ & 59 & $0 / 75$ \\
\hline DI3SI75* & $13(18.7)$ & Direpeat & $(\mathrm{CA}) n$ & 36 & $0 / 48$ \\
\hline$D / 4 S 72$ & 14 (19.4) & Direpeat & $(\mathrm{CA}) n$ & 48 & $0 / 75$ \\
\hline D/4S69 & $14(35.1)$ & Direpeat & $(\mathrm{CA}) n$ & 44 & $0 / 75$ \\
\hline$D / 7 S / 157$ & 17 (27.7) & Tetrarepeat & $(T G A A) n$ & 26 & $0(44)$ \\
\hline$D / 7 S 250 *$ & $17(37.5)$ & Di- + direpeats & $(\mathrm{TA}) n+(\mathrm{CA}) n$ & $53+33$ & 2/75 (L86, T67") \\
\hline$D / 7 S / 787^{c}$ & $17(40.1)$ & Direpeat & (CA)n & 40 & $0(44)$ \\
\hline DI $7 S 856$ & $17(40.7)$ & Tetrarepeat & $(\mathrm{GAAA}) n$ & 184 & $0 / 44$ \\
\hline$D 2 I S 4 I I$ & ? (I or 22$)$ & Di- + Tetrarepeats & $(\mathrm{CA}) n+(\mathrm{CATA}) n$ & $50+70$ & $0(44)$ \\
\hline DYSI9 & $Y(9.1)$ & Tetrarepeat & (TAGA)n & 66 & $0 / 44$ \\
\hline
\end{tabular}

*Recommended MSI markers for diagnosis and research by the NCI MSI Detection Workshop (Boland et al., 1998).

"These tumors have two positive MSI markers including D3SI 754 among the 75 tumors examined.

a Marker D3SI 754 is at 178.8-Mb of $3 q$ (as of February 2004) and is within the core-amplified domain. EAs positive for MSI with this marker are A07, D06, D66," 163," L86," M28, M60, M55, S08, B95, V65," W61."

${ }^{\circ}$ Bat-2I spans the sequence between $3^{\prime}$ end of intron II and $5^{\prime}$ site of exon 12 of human MLHI gene. PCR fragment of Bat-26 intersects intron 4 and exon 5 of the $h M S H 2$ gene.

${ }^{C}$ Markers DI 75250 (37.5-Mb) and DI 7SI 787 (40.I-Mb) are 0.8 and I.8-Mb telomeric, respectively, to the ERBB2 (38.3 Mb) oncogene. ERBB2 represents the most frequently amplified amplicon (21.8\%) in esophageal adenocarcinoma (Miller et al., 2003b).

NCI guidelines of MSI in cancer detection (Boland et al., 1998). Another five markers were of the (TAGA) $n$ type, analogous to marker D3S1754. Forward primers were ${ }^{32} \mathrm{P}$-labeled, and PCR was applied to the DNA from normal-tumor pairs. Additional novel MS fragments within the $3 \mathrm{q}$ and $E R B B 2$ amplicons were designed using the Repeat Masker Server (repeatmasker.genome.washington. edu) and analyzed. Primer sequences are given in the Supplementary Table (supplementary material for this article can be found at http://www. interscience.wiley.com/jpages/1045-2258/suppmat). The GenBank accession numbers of microsatellite fragments 3q112136-3 and $17 q b 2-1$ are DQ157857 and DQ157856, respectively. Mutation analysis of $M S H 3$ and $M S H 6$ was performed according to the modifications from Yin et al. (1997).

A tissue microarray (TMA) block was constructed according to Kononen et al. (1998). The TMA contained multiple cores of 64 EA resections from 59 patients, 8 lymph node metastases, 8 dysplastic Barrett's mucosas, 11 Barrett's mucosas, and 10 normal controls from various tissues. Sections were incubated with antibodies against MLH1 (1:100 dilution; BD Biosciences, San Diego, CA; cat. no. 554073) or MSH2 (1:100 dilution; Oncogene Research Products, Boston, MA; cat. no. NA27). Microwave citric acid epitope retrieval was performed for $20 \mathrm{~min}$ for both antibodies. Each slide was lightly counterstained with hematoxylin. 


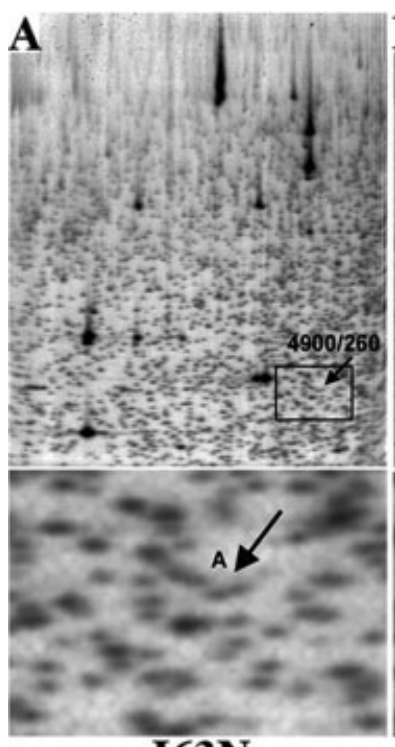

I63N

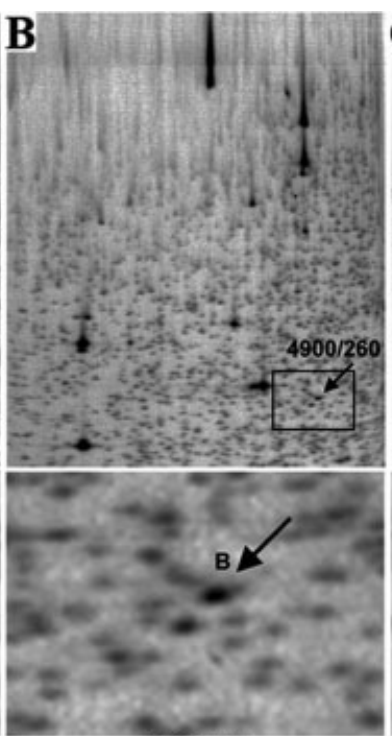

I63T

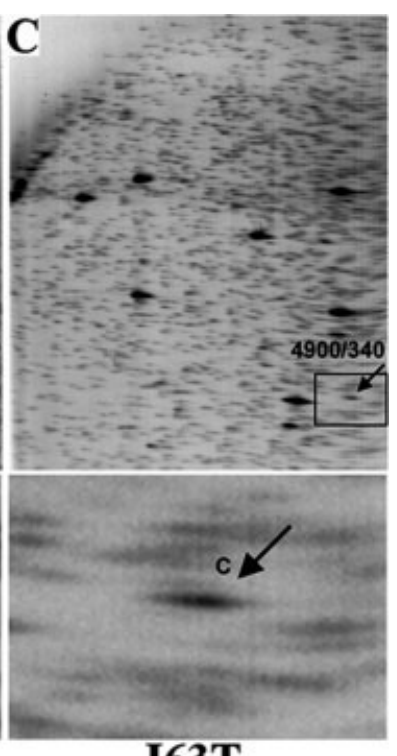

I63T
Figure I. Identification of intrachromosome amplification in EA DNA using RLGS. The numbers represent the restriction sizes in I-D (4,900 bp) and 2-D (260 bp for Notl/Hinfl digestion and 340 bp for Notl/Dpnll) gels. An enlarged area of the respective target fragment is shown in the panels underneath. (A) Restriction Notl/Hinfl fragments from normal DNA of patient 163 were resolved on 2-D RLGS gels. (B) Two-dimensional gel image of EA 163. A comparison between normal and tumor gel images reveals a fragment that increased in density in the EA (arrow in $B$ ) relative to the corresponding normal (arrow in A). (C) Notl/Dpnll digestion was performed for cloning purposes. Fragment $C$ (arrow) was cloned directly from the 2-D gel. The very intense fragments visible on these gels represent ribosomal DNA, present in multiple copies in the genome.

\section{Southern Blot and Array CGH Analyses}

EST AW513672 (nt5635-2) and PIK3CA were used as probes and hybridized to Southern membranes containing six pairs of normal-EA DNA using standard hybridization and washing conditions. Array $\mathrm{CGH}$ was performed as previously described (Pinkel et al., 1998).

\section{RNA Isolation and Quantitative RT-PCR}

Total RNA was isolated using Trizol reagent (Invitrogen, Carlsbad, CA). All the RNA samples were treated with DNase I (Promega, Madison, WI) prior to performing reverse transcription. Two micrograms of total RNA was reverse-transcribed (Invitrogen, Carlsbad, CA) and primed by both $(\mathrm{d} T)_{18}$ and random hexamers in a $20-\mu$ l reaction volume. One microliter of the cDNA products underwent RT-PCR using $G A P D H$ as a coamplified internal control. The RT-PCR products were resolved on $8 \%$ denaturing $\mathrm{PAGE}$ gels and analyzed using ImageQuant (Amersham Biosciences).

\section{Reverse Northern Blot Analysis}

Eight BAC clones covering the chromosome 3q26.3-q27 region from 178.4- to $180.6-\mathrm{Mb}$ were selected. BAC clone RP11-245C23 (BAC3K) was kindly provided by Dr. Steve Scherer, Baylor College of Medicine. All the remaining BACs were purchased from BACPAC Resources (Children's Hospital, Oakland Research Institute, Oakland, CA). BAC DNA was prepared as previously described (Lin et al., 2002) and digested using the EcoRI restriction enzyme. Tumor or normal RNA from patient M28 was reverse-transcribed with oligo(T) and $\left[\alpha-{ }^{32} \mathrm{P}\right] \mathrm{dC}$ TP for direct incorporation for the synthetic cDNA, then hybridized to the arrayed BAC membrane.

\section{Affymetrix Microarray Assays}

Forty-six samples including nondysplastic and dysplastic Barrett's mucosas and EAs were subjected to gene expression profiling using Affymetrix U133A chips (Affymetrix, Santa Clara, CA) as previously described (Giordano et al., 2001).

\section{DNA Sequencing}

All IMAGE cDNA clones were purchased from Open Biosystems (Huntsville, AL), and plasmid DNA was prepared using a QIAprep ${ }^{\circledR}$ Spin Miniprep kit (Qiagen). The GenBank accession numbers of the full-length insert sequencing are AY679731 for IMAGE 2737847, AY679732 for IMAGE 2344756, and AY769439 for IMAGE 4345107. DNA was sequenced by the University of Michigan Sequencing Core.

\section{RESULTS}

\section{A Cloned Restriction Fragment Amplified in EA Is Mapped to 3q26.3-q27}

We used two-dimensional (2-D) RLGS to investigate genomic amplification in 44 primary EAs. More than 2,000 individual Not $\mathrm{I} /$ Hinf I restriction fragments were visualized and used to compare the 2-D images of normal and tumor DNA (Fig. 1). In one patient (EA I63), we identified a NotI/HinfI 
Figure 2. $\mathrm{CGH}$ and interphase FISH images. (A) The composite CGH profile demonstrates that increased genomic dosage with an intrachromosomal pattern maps to 3q26-q27 (red bar) in EA 163 DNA. (B) Interphase FISH analysis and hybridization with BAC probe AC076966 containing the 2-D RLGS fragment (green) show increased copy numbers in the EA 163 nuclei but not in unamplified EA W40. The bright green signal in tumor EA 163 may suggest an aggregate of multiple smaller components, indicating overall increased DNA copy numbers. In addition, the right panel shows many smaller individual components adjacent to each other (green dots), indicating both increased copy numbers and the specificity of the probe hybridization. A metaphase preparation is shown as a control (left panel). The metaphase spreads were prepared from a human lymphoblast cell line that does not contain genomic amplification. A control probe (I4q, red) was cohybridized and is visible in the subset of the two interphase nuclei as well as in the metaphase chromosome. Because the preparations of interphase nuclei in the middle and right panels were from touch preps of primary tumors, the red control signals are localized in many planes because of the three dimensions of the tumor cell aggregates and may not be visible in every interphase tumor nucleus in the same plane.

A
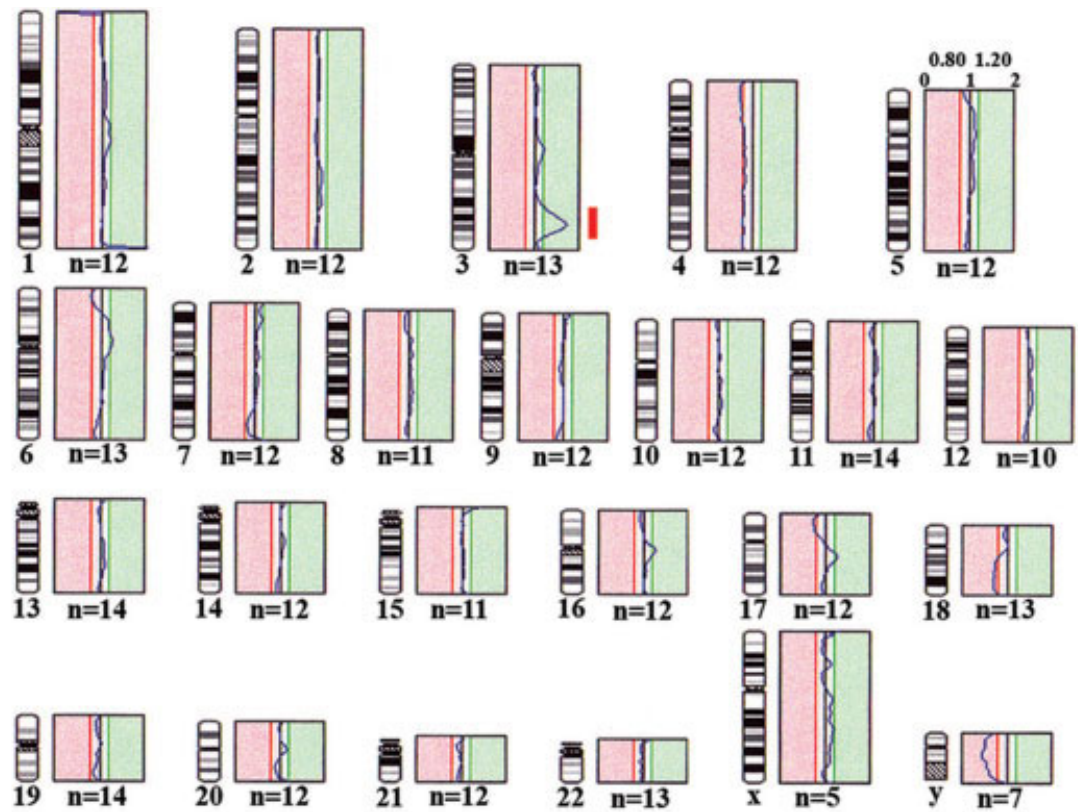

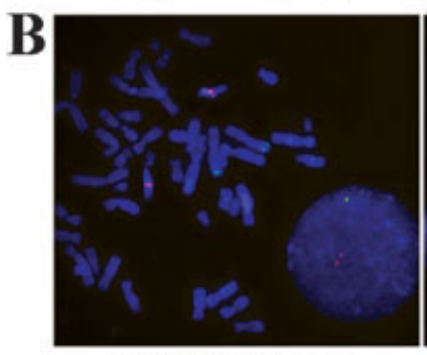

Metaphase

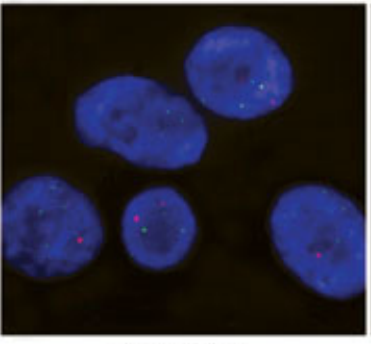

W40T

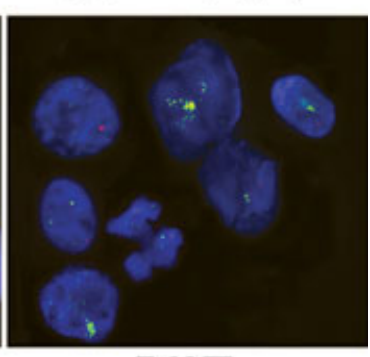

I63T
DNA fragment that was amplified in the primary EA (Fig. 1B), but not its matched normal DNA (Fig. 1A). A corresponding 343-bp fragment from NotI/DpnII restriction digestion (Fig. 1C) was cloned, and the sequence of the cloned fragment was found to be identical to a sequence within BAC clone AC076966, which maps to chromosome band 3q27.1 (www.ncbi.nlm.nih.gov). We then performed $\mathrm{CGH}$ analysis on 3 of the $44 \mathrm{EAs}$ including the EA (I63) that demonstrated the amplified NotI/ DpnII fragment in RLGS assay (Fig. 2A). CGH verified that the EA I63 DNA had an increased genomic dosage at 3q26-q27(Fig. 2A). Moreover, interphase FISH performed on EA I63 demonstrated an increased copy number when probe AC076966 DNA was hybridized and compared with non-3q-amplified EA and the metaphase control (Fig. 2B).

\section{Two Amplicons Identified in 3q26.3-q27 Region}

To characterize and fine-map the $3 q 26.3-q 27$ amplification, we designed a series of STS/EST/ gene markers extending more than $5-\mathrm{Mb}$ in both directions from the location of the 2-D fragment. We applied these markers to 75 pairs of EAs and their matched normal DNA, which included most of the 44 EA samples we had analyzed in the 2-D RLGS assays. STS-amplification mapping revealed that 7 of $75(9.3 \%)$ EAs, 3 of $33(9.0 \%)$ lung adenocarcinomas, and 1 of $24(4.2 \%)$ esophageal squamous carcinomas demonstrated amplification at 3q26.3-q27 (Fig. 3A). Two amplification units were identified in the 10-Mb segment (Figs. 3A and 4). The proximal $3 \mathrm{q}$ amplicon encompassed the TERC and SKIL loci, whereas the distal amplified-core region mapped between D3S3096 and WI-13792 (Figs. 3A and 4). EA M28 exhibited the highest copy number (>10-fold) at marker D3S1754 (Fig. $3 \mathrm{~B})$, but was not amplified at the PIK3CA locus (Fig. 3A). DNA copy number remained unchanged at control markers on the chromosome 3 centromere and $3 \mathrm{p}$ telomere, respectively, indicating that the amplicon in all affected tumors was intrachromosomal (Fig. 3C). These centromeric or telomeric sequences of chromosome 3 were used as 


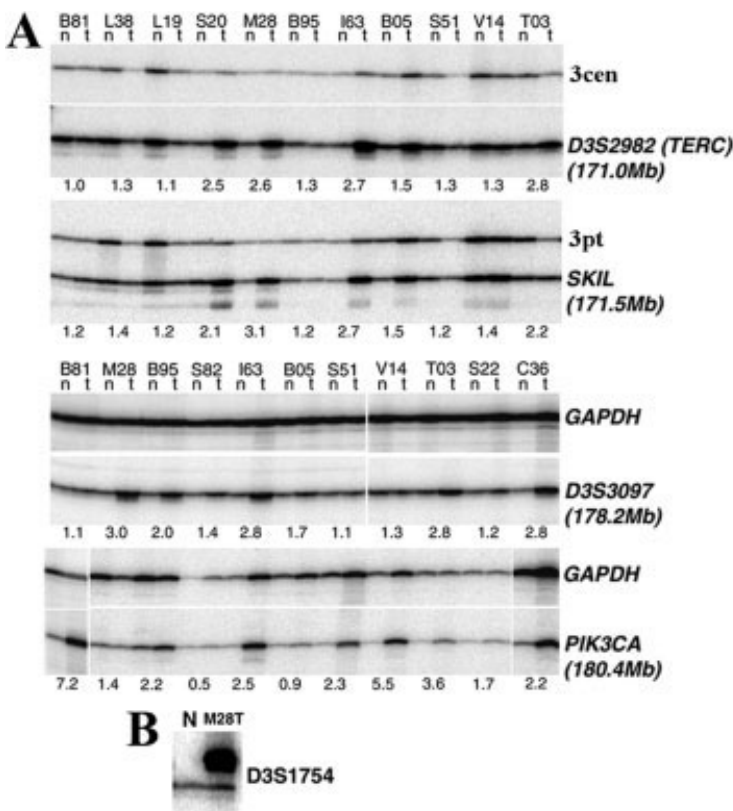

Figure 3. Two amplification units identified in the chromosome $3 q 26.3-q 27$ region. (A) STS/gene markers selected from the 3q26.3q27 region were examined in the normal-EA or normal-lung tumor pairs, using QG-PCR with GAPDH or sequences from the centromere and telomere of chromosome 3 as controls. The radiation-labeled PCR products were resolved in polyacrylamide gels, and densitometry was performed. A comparison of the magnitude of genomic amplification in each pair was calculated using the formula [tumor (marker/control)/ normal (marker/control)]. Genomic amplification in EA S20 was detected only in the proximal region (top two gel panels), whereas DNA amplification at or extended into the distal amplicon was found in six EAs (bottom two gel panels), as summarized in Figure 4. (B) The highest DNA copy number ( $>10$-fold) of the D3SI 754 locus was found

internal controls for the multiplex PCR reactions, similar to the use of $G A P D H$ as the internal control (Fig. 3A).

Array CGH of four pairs of EA and matched Barrett's DNA from the pool of 75 DNA samples used in this study revealed two peaks exhibiting an increase in DNA dosage in EA B05 at 3q26-q27 (Fig. 3D), consistent with the mapping results presented in Figure 3A. The centromeric peak was linked to the TERC and SKIL loci (BAC clone RP11-141C22); and the copy number of the PIK3CA locus was unchanged in this EA (Fig. 3D). The telomeric peak lay outside the $10-\mathrm{Mb}$ mapping region in EA B05 (Fig. 3D). Southern blot analysis of EA M28 and B05 demonstrated increased DNA dosage at $179.7-\mathrm{Mb}$ using probe AW513672 but not with the probe containing PIK3CA (data not shown). Together, the above data identified two amplicons within the $10-\mathrm{Mb}$ region in a subset of EAs, and the telomeric amplifiedcore domain may likely exclude PIK3CA as a candidate gene for amplification in EA (Fig. 4).

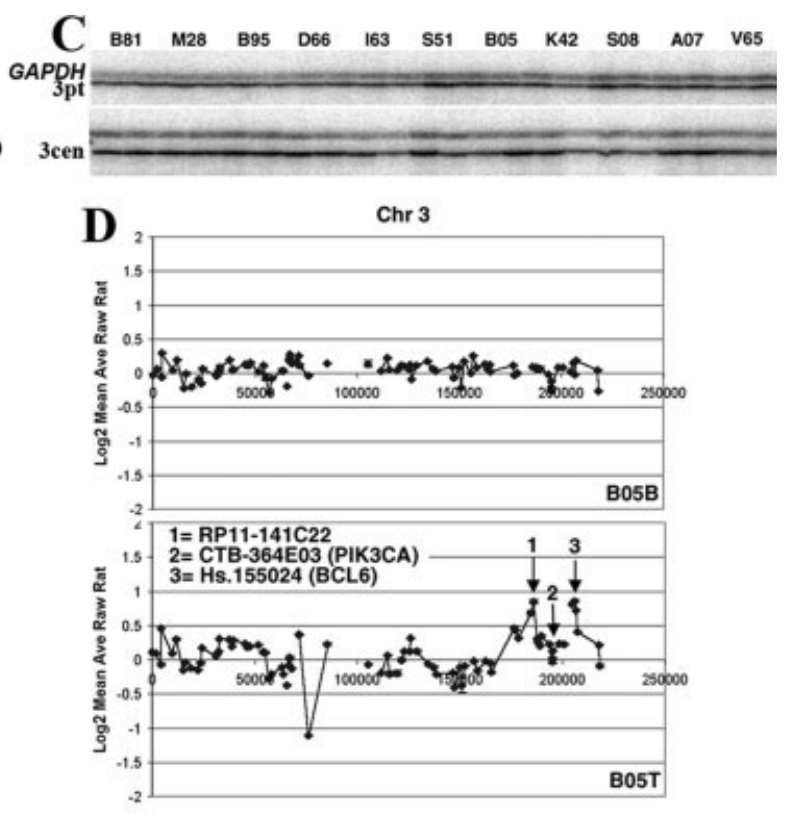

in EA M28, appearing in the newly replicated MSI allele (top allele) as compared with the normal DNA. (C) Two DNA fragments from the chromosome 3 centromere and $3 p$ telomere were PCR-coamplified with GAPDH in all normal-EA pairs. No increase or decrease in DNA copy number was found after densitometry. (D) Array CGH analysis revealed increased genomic dosage (two peaks) in EA B05 as compared to its associated Barrett's metaplastic DNA. The proximal peak (arrow I) involves BAC RPII-I4IC22 sequence, which is closely linked to the TERC and SKIL loci. The distal peak (arrow 3) is the BCL6 locus, which is outside the 10-Mb mapping area. Copy number of the PIK3CA gene (arrow 2) was unchanged in EA B05, which is consistent with the QGPCR results (Fig. 3A).

\section{Frequent Microsatellite Instability Found at D3SI 754 and Regional MSI Precedes Nascent Allele Amplification during EA Tumorigenesis}

Analysis of the distal 3q26.3-q27 amplicon in the EAs also revealed that amplification often affected only one allele, with the second allele either unchanged or deleted in the EA genome (Fig. 5A). These results might account for the inability to detect an increase in DNA copy number when a nonpolymorphic marker was used.

Further analysis of the 3q26-q27 amplicon revealed relatively frequent MSI at marker D3S1754 (16.0\%) in EAs, which was in stark contrast to the genomewide microsatellite stability (MSS) and/or low frequency of MSI (MSI-L, 2.6\%, $P<0.005$, standard $\chi^{2}$ test) commonly observed in EA (Fig. 5B and Table 1). D3S1754 resides in the distal amplified core and showed the highest DNA copy number in EA M28 (Fig. 3B). Interestingly, amplification was detected in the newly replicated MSI allele in EA M28 (Fig. 5B), prompting us to investigate the possible relationships between 


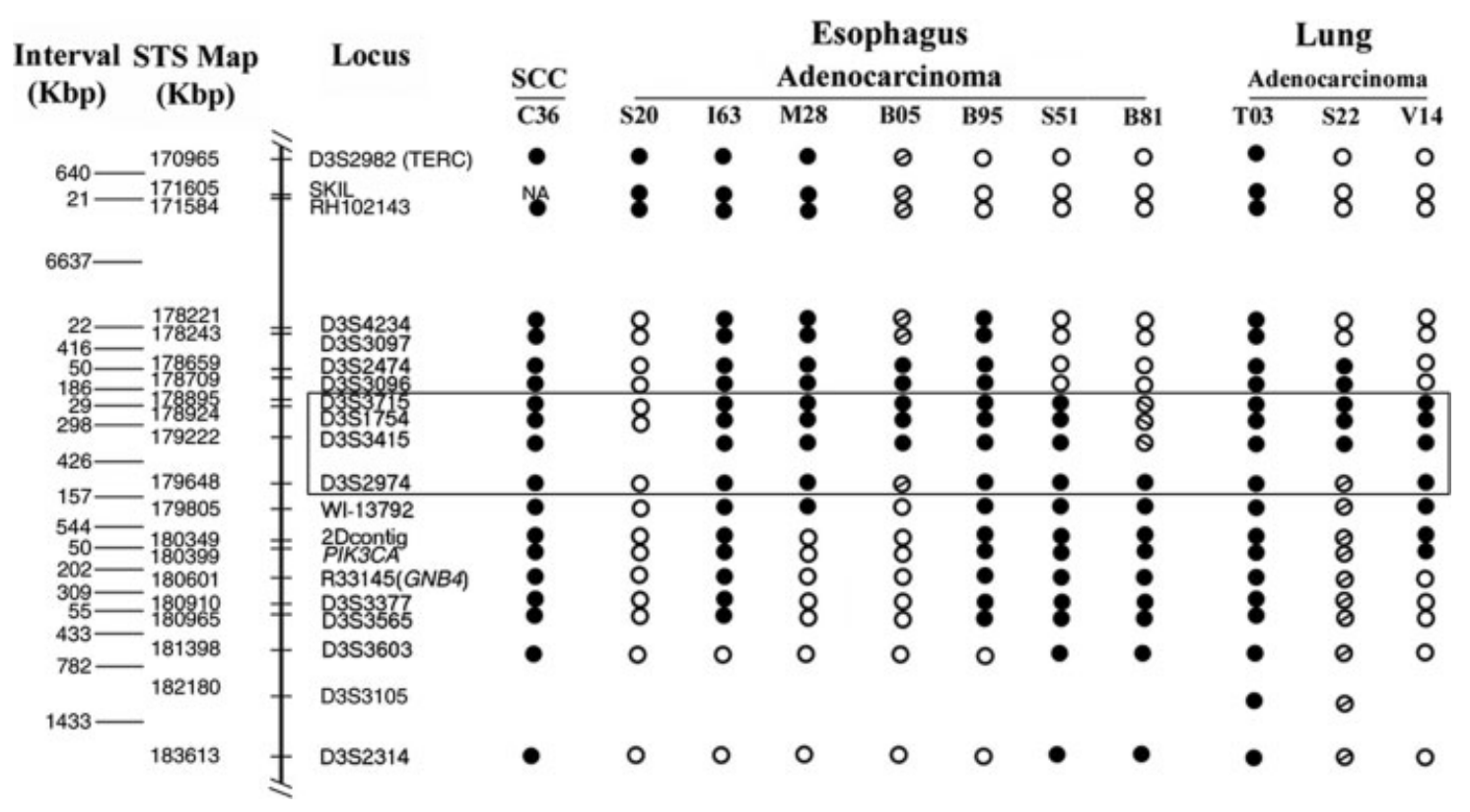

Figure 4. Diagrammatic map summarizing the 3q26.3-q27 amplicons detected in an examination of 75 EAs, 33 lung adenocarcinomas, and 24 esophageal squamous carcinomas using QG-PCR. A bullet indicates genomic amplification, defined as a ratio of [tumor (marker/control)/normal (marker/control)] $\geq 2.0$; an $\varnothing$ indicates DNA copy number gain (ratio between I.5 and I.9), and a $\bigcirc$ indicates no genomic amplification. The boxed region defines the distal amplified-core domain.

regional MSI and 3q amplification. We did not find mutations in MSH3 and MSH6. Both MLH1 and MSH2 were abundantly expressed at the protein level as shown by immunohistochemistry on tissue microarrays (TMA) in D3S1754-MSI ${ }^{(+)}$EAs (data not shown). We concluded that amplification may not be responsible for D3S1754-MSI because: (a) D3S1754-MSI occurring in premalignant dysplastic Barrett's mucosa and preceding the genomic amplification that arose only in the EA though allelic imbalance could be observed as early as in the premalignant Barrett's DNA (Fig. 5C); (b) only 2 of 7 amplified EAs were D3S1754-MSI ${ }^{(+)}$and 2 of 12 D3S1754-MSI ${ }^{(+)}$EAs developed 3q amplification (Figs. 4 and 5B); (c) other microsatellites within both the 3q26.3-q27 and ERBB2 amplifiedcore regions were stable in the D3S1754-MSI ${ }^{(+)}$ EAs (data not shown); and (d) D3S1754-MSI was positive in four MS-unstable $\left(\mathrm{MMR}^{-}\right)$colon cancers, whereas it was negative in all five MS-stable colon cancers examined (Fig. 5D). Thus, microsatellite D3S1754 is highly unstable in both EA $\left(\mathrm{MMR}^{+}\right)$and colon cancers regardless of MMR proficiency.

Furthermore, the identical genotype of the nascent D3S1754-MSI alleles between Barrett's dysplasia and the corresponding EAs provided molec- ular evidence that EA is derived directly from Barrett's dysplasia by clonal expansion (Fig. 5C).

\section{Seven ESTs Mapped within Distal 3q Amplified Core Are Overexpressed in EA}

We next implemented a reverse Northern blot assay to identify differentially expressed transcripts within the amplified-core region. Two of eight arrayed BAC DNAs that map within the amplifiedcore showed increased expression in EA M28 RNA (Fig. 6A). Fifteen ESTs, including eight within the two BACs (BAC1 and BAC3, Fig. 6A), were screened by quantitative RT-PCR (Fig. 6B and C). Overexpression of seven ESTs was detected in EAs containing the distal amplicon (Fig. 6B and C). We also used U133A microarrays to analyze expression-profiling data at 3q26.3-q27 in 46 samples including samples of Barrett's metaplasia, dysplasia, and EA. Although increased PIK3CA expression was found in 3 of $15 \mathrm{EAs}$, none of these three contained the $3 \mathrm{q}$ amplicon, suggesting increased expression of PIK3CA resulted from transcriptional alterations (data not shown). These results supported the previous notion that PIK3CA was not part of distal $3 \mathrm{q}$ amplicon. One of the overexpressed ESTs, $n t 5635-3$, is a part of KCNMB2. EST 


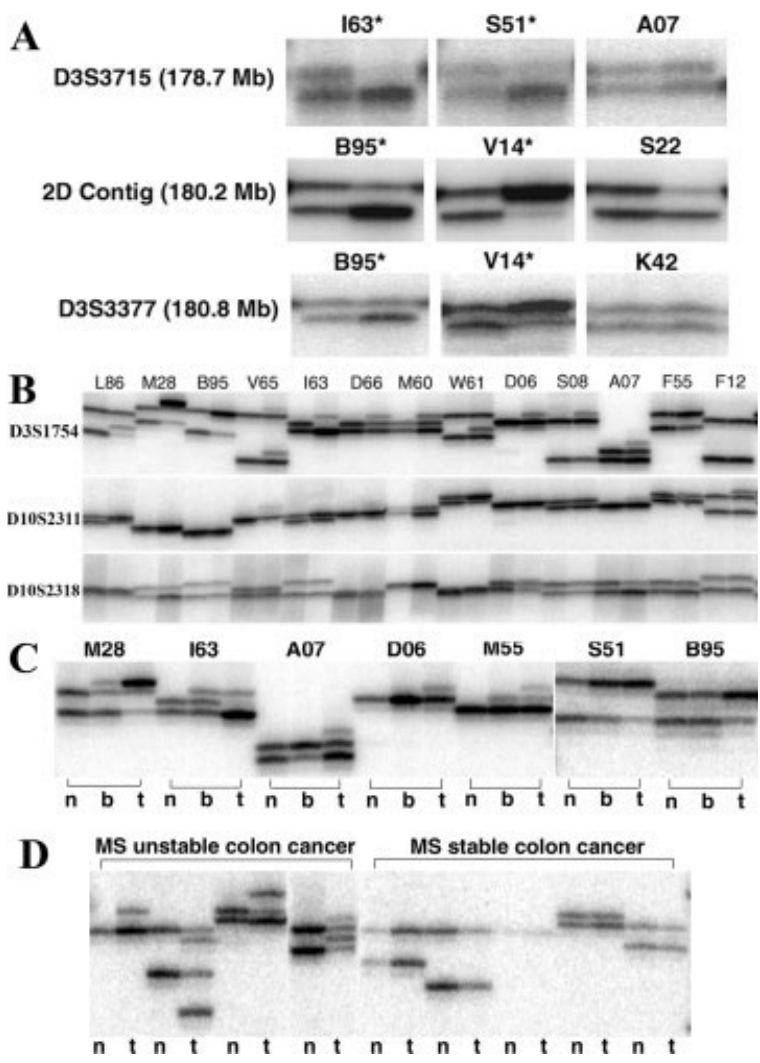

Figure 5. Allelic amplification detected in EAs and marker-specific MSI preceded genomic amplification during EA development. In the paired samples from each patient in both $(A)$ and $(B)$, the normal is on the left and the tumor on the right. (A) Allelic amplification in conjunction with deletion/no change of the second allele was found in EAs using polymorphic markers within the 3q26.3-q27 amplicon. Samples marked with an asterisk indicate the 3q26.3-q27 region was amplified in that tumor DNA. (B) Microsatellite D3SI 754 demonstrating frequent MSI and amplification in the newly replicated MSI allele in EA M28. DIOS23II and DIOS23/8, 2 of 29 additional MS markers examined, represent genomewide MSS in 75 EAs (Table I). (C) D3SI754-MSI also detected in dysplastic Barrett's samples M28 and 163; however, genomic amplification developed only in the corresponding EAs. EA M55 showed progressive $\mathrm{MSI}$, as only one newly replicated MSI allele was observed in dysplastic Barrett's DNA, but an additional MSI allele was detected in the corresponding EA. Allelic imbalance observed in dysplastic A07 with DNA loss in one of the alleles. (D) Four pairs of MS unstable and five stable colon cancers with matching normal DNA were tested for D3SI754-MSI. All microsatellite-unstable tumors are D3SI754-MSI ${ }^{(+)}$ and microsatellite-stable tumors are negative.

$n t 5635-7$ is a portion of a $1.25-\mathrm{kb}$ transcript (GenBank accession number AY686686; Fig. 7A).

\section{5'UTR Initiates Chimeric Cellular Transcripts in Primary EA and EA Cells, and the 3q Chimeric Transcript Is Amplified and Overexpressed in EAs}

Intriguingly, one of the seven overexpressed ESTs, $n t 5635-2$ (hereafter termed esophageal adenocarcinoma amplified sequence 2, EAAS2), is identical to the $3^{\prime}$ end of a chimeric transcript (AF279780) that likely was initiated from the antisense promoter (ASP) of a full-length long inter- spersed element-1 (LINE-1 or L1; Fig. 7A). Sequence analysis of seven IMAGE cDNA clones analogous to L1-5'ASP/EAAS2 from various cell or tissue sources validated the observed RT-PCR products from the EA samples (Fig. 7B and C; and see GenBank IDs in Materials and Methods section). We also determined that L1-5'ASP/EAAS2 was spliced from 5-8 exonlike structures all residing within the distal amplified core (Fig. 7A and C). As shown, L1-5'ASP/EAAS2 is differentially expressed not only in EA cells but also in primary EAs (Fig. 7B). In addition, we also identified nine CpG islands in this L1-5'ASP (Fig. 7D).

Given the above data, we next investigated the possible consequence of L1 $5^{\prime}$ ASP activity in other EA amplicons. We selected from the GenBank database two L1-5'ASP-associated cDNAs in known amplicons, L1-5'ASP/MET (BF208095), at 7q31.3, and L1-5'ASP/BCAS3 (AU123136), at 17q23, encoding portions of the MET oncogene and the BCAS3 gene, respectively (Fig. 8). BCAS3 is a gene of unknown function that commonly is amplified in breast cancer (Barlund et al., 2002). RT-PCR analyses revealed that $\mathrm{L} 1-5^{\prime} \mathrm{ASP} / M E T$ and $\mathrm{L} 1-5^{\prime} \mathrm{ASP} /$ $B C A S 3$ were differentially expressed in both primary EAs and EA cell lines (Fig. 8A). Interestingly, the expression of L1-5'ASP/MET was found only in EAs containing $M E T$ amplification and in two EA cell lines (Fig. 8A). L1-5'ASP in L1-5'ASP/MET and L1-5'ASP/BCAS3 were both found within the introns of the two genes, initiating two truncated gene forms, respectively (Fig. 8B).

\section{DISCUSSION}

Genomic amplification is often detected in cancer (Knuutila et al., 1998) and is an important mechanism for activating proto-oncogenes, resulting in high-level expression of the selected gene products (Bishop, 1987). Two-dimensional RLGS allows the comparison of greater than 2000 restriction fragments between normal and tumor DNA isolated from the same patient (Kuick et al., 1995), and cloning of an affected 2-D RLGS spot leads directly to the identification and localization of amplicons in the cancer genome (Hughes et al., 1998; Lin et al., 2000b). Genomic amplification at $3 q 25-q 27$ has been observed in several human cancers, suggesting the presence of genes that may have roles in the development or progression of multiple cancer types. In most studies, CGH defined the minimal amplified region as a large DNA segment of several megabases, making it difficult to identify a specific candidate gene responsible for tumor development (Ma et al., 2000; Guan 


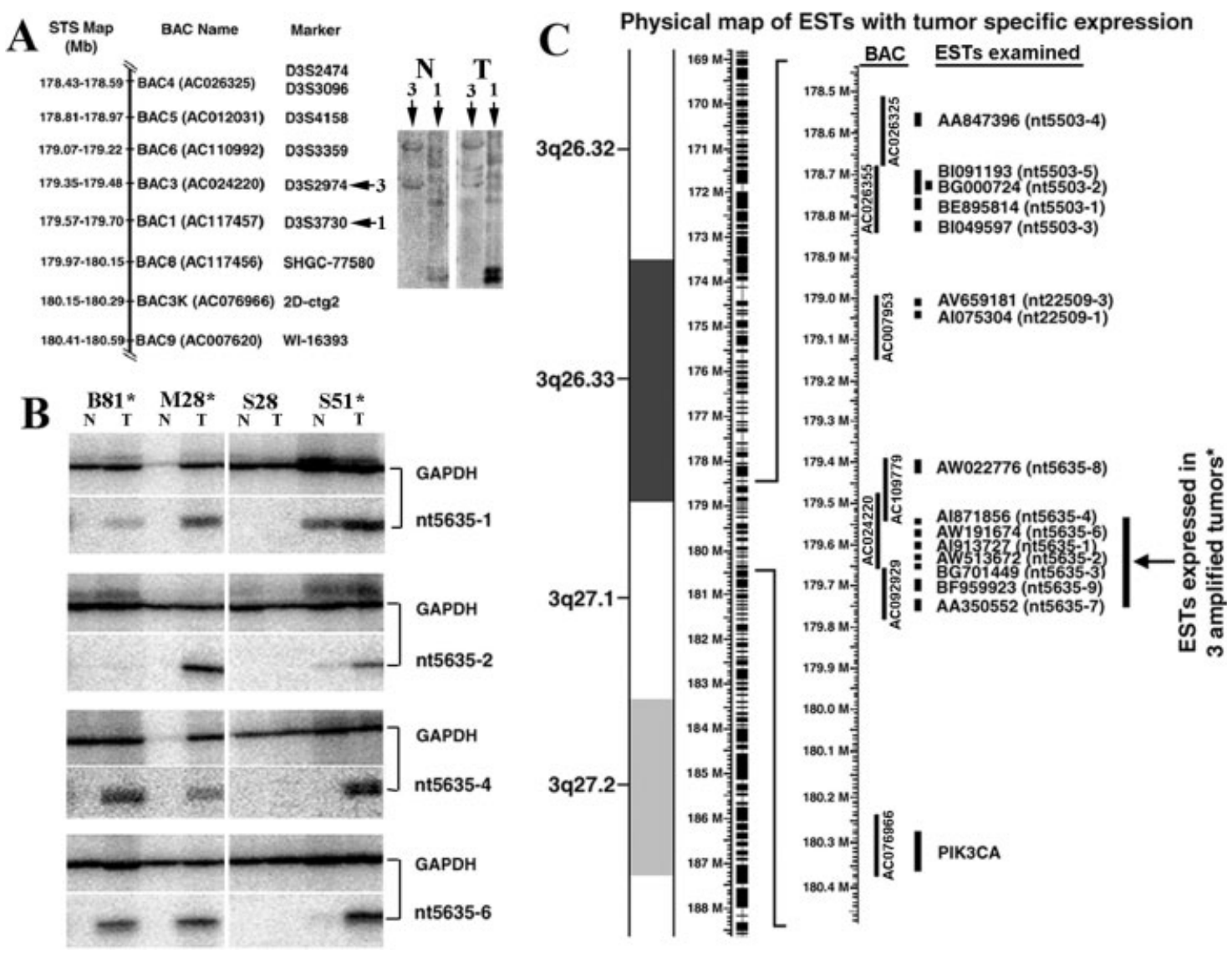

Figure 6. Differential RNA expression in EAs containing the distal 3q26.3-q27 amplicon. (A) Reverse Northern blot analysis showing that two of eight arrayed BAC DNA samples demonstrated increased RNA expression in EA M28 relative to the matched normal RNA. These two BACs (AC024220 and ACI I7457) cover the sequences mapped from I79.4 to I79.7-Mb within the distal amplified core. (B) Quantitative RTPCR analysis of the ESTs selected around and within the distal ampli-

et al., 2001; Imoto et al., 2001; Singh et al., 2001; Redon et al., 2002; Heselmeyer-Haddad et al., 2003). In the present study, we were able to finemap the core amplified domain to a less than a 1$\mathrm{Mb}$ region at chromosome band 3q26.3-q27. Seven ESTs within this amplified-core domain were found to be overexpressed or only expressed in EAs. Genomic amplification was found to be involved in only one allele when a group of polymorphic microsatellites was examined in EAs. The allelic amplification observed may support the common disease/common variant (CD/CV) hypothesis (Lander, 1996) and, most importantly, suggests the necessity of using both microsatellite polymorphisms and single-nucleotide polymorphisms (SNPs) to identify the risk allele within a specific EA amplicon.

We observed specific microsatellite instability (MSI) at marker D3S1754, which is in stark contrast to the genomewide microsatellite stability (MSS) and/or low frequency of MSI commonly fied-core region. Elevated expression of seven ESTs mapped within the amplified core was detected in the EAs containing the amplicon. Samples with an asterisk represent amplification of the 3q26.3-q27 region in the tumor DNA. (C) Diagram summarizing the selected ESTs and differential expression patterns from RT-PCR analysis in the 3q26.3-q27 region. Results for ESTs with RNA overexpression (vertical bar, arrow) were consistent with the results from the reverse Northern blot assay.

observed in EA (in the present study and from Muzeau et al., 1997; Kulke et al., 2001). Interestingly, this unstable D3S1754 demonstrated the highest DNA copy number in the 3q26.3-q27 amplicon in tumor M28 (Fig. 3B). MSI may result from a pronounced deficiency of mismatch repair (MMR; Strand et al., 1993), yet genomewide MSS in EA indicates intact MMR. Consistent with this idea, we did not find mutations in MSH3 and MSH6 and demonstrated that both MLH1 and $\mathrm{MSH} 2$ were abundantly expressed at the protein level in D3S1754-MSI ${ }^{(+)}$EAs. The increased DNA polymerase slippage in the amplified region that results in frequent MSI at marker D3S1754, therefore, might be attained by an MMR-independent mechanism. Moreover, microsatellites selected from the ERBB2 amplicon were demonstrated to be MSI negative in EAs, suggesting that genomic amplification may not be associated with the origination of the marker-specific MSI found 
A
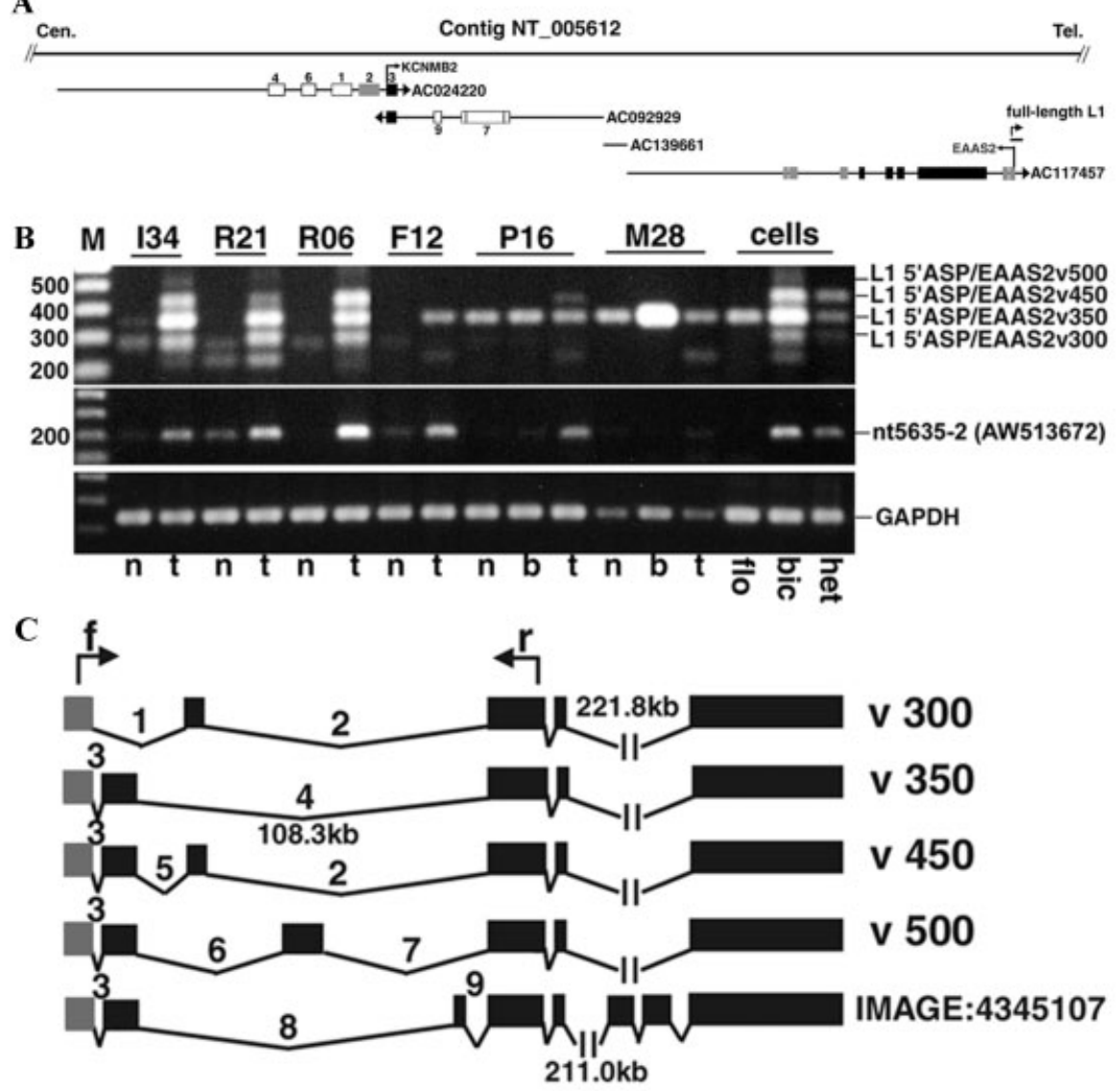

\section{GCCAGgtgag .. agaagATGTG \\ 2 GAACTgtgag .. tgcagGCATT \\ 3 GCCAGgtgag .. tttagAGATG \\ 4 TACAGgtatg .. tgcagGCATT \\ 5 TACAGgtatg .. agaagATGTG}

\section{TACAGtgatg .. tccagGCACT \\ 7 AGCAGgtata .. tgcagGCATT \\ 8 TACAGgtatg .. agaagGAAAT \\ 9 GAGAGgtaag .. tgcagGCATT}

D

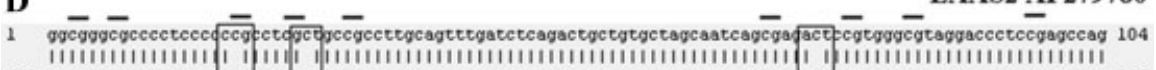

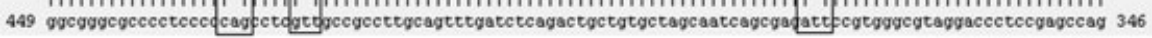

Figure 7. Chimeric LI 5'ASP/ cellular transcripts were identified and found to be differentially expressed in EAs. (A) Diagram of seven amplified ESTs showing increased expression in the EAs in the $0.5-\mathrm{Mb}$ amplified-core region. Numbers above each open or solid bar represent the EST series nt5635 examined in this study (Fig. 6B and C). The arrow above the number shows the transcription orientation The Sequence of $n t 5635-2$ (EAAS2) is identical to the $3^{\prime}$ end of a multiexon transcript, initiated by $\mathrm{LI}$ 5'ASP (solid gray bars). A 6.2-kb full-length $\mathrm{LI}$ retrotransposon is mapped adjacent to EAAS2 in an opposite transcription direction. (B) RT-PCR products resolved on a $1.0 \%$ agarose gel. Differentially expressed LI-5'ASP/EAAS2 as well as transcription variants are shown. (C) Schematic of transcription variants of LI-5'ASP/EAAS2. $r$ with arrows indicate forward and reverse primers for RT-PCR. Numbers representing each splicing structure are indicated. Uppercase indicates exon sequences, and lowercase indicates introns. Gray bars represent LI-5'ASP sequences. (D) Sequence alignment between the LI.2 promoter sequence (M80343) and the 104-bp LI-5'ASP sequence of the 5'ASP/EAAS2 transcript. A short line above highlights each of nine CPG islands. with $D 3 S 1754$ in this study. ERBB2 is the most frequently amplified gene in EA (Miller et al., 2003b). Previous studies have shown that mismatch repair is microsatellite repeat-unit size dependent. Although the mutation rates are similar in MS tetra-, di-, and monorepeat fragments, Sia et al. (1997) showed that repair of tetranucleotide repeats may be less efficient than repair of monoand direpeat microsatellites in yeast models. Nonetheless, sporadic microsatellite mutations, elevated microsatellite instability at selected tetranucleotide repeats (EMAST), in particular, are distinct forms of MSI because of a lack of MMR dependence and have been reported in many cancers (Ahrendt et al., 2000; Danaee et al., 2002; Catto

LINE1.2 M80343

et al., 2003). Studies have shown that endogenous production of oxygen free radicals and carcinogeninduced DNA damage may promote instability of microsatellite sequences (Jackson et al., 1998; Slebos et al., 2002). D3S1754, at 3q26.3-q27, is a $($ TAGA) 98 tetranucleotide microsatellite. Taken together, D3S1754-MSI may reflect genetic and/or environmental insults from gastroesophageal reflux and/or inflammation in EA, and the resultant sporadic MSI may be a result of less efficient mismatch repair of this particular tetranucleotide repeat. Interestingly, colorectal cancers with MMR-dependent MSI have been found to be near-diploid and do not show the increased rates of chromosome losses and gains that are characterized as chromo- 
Figure 8. Differential expression of the LI-5'ASPIMET and LI-5'ASP/ BCAS3 in EAs and EA cells. (A) Differential expression of LI-5'ASP/BCAS3 in EAs. Expression of the LI-5'ASP/ MET oncogene was found only in EAs 134 and R21, tumors containing $7 \mathrm{q} 31$ amplification, and in two EA cell lines. Transcription variants also were identified in both chimeric transcripts. (B) Diagrams for the variants of LI-5'ASPI BCAS3 and LI-5'ASPIMET with RTPCR primer sites (arrows). Gray bars represent LI-5'ASP sequences and black bars the corresponding MET and $B C A S 3$ genes.
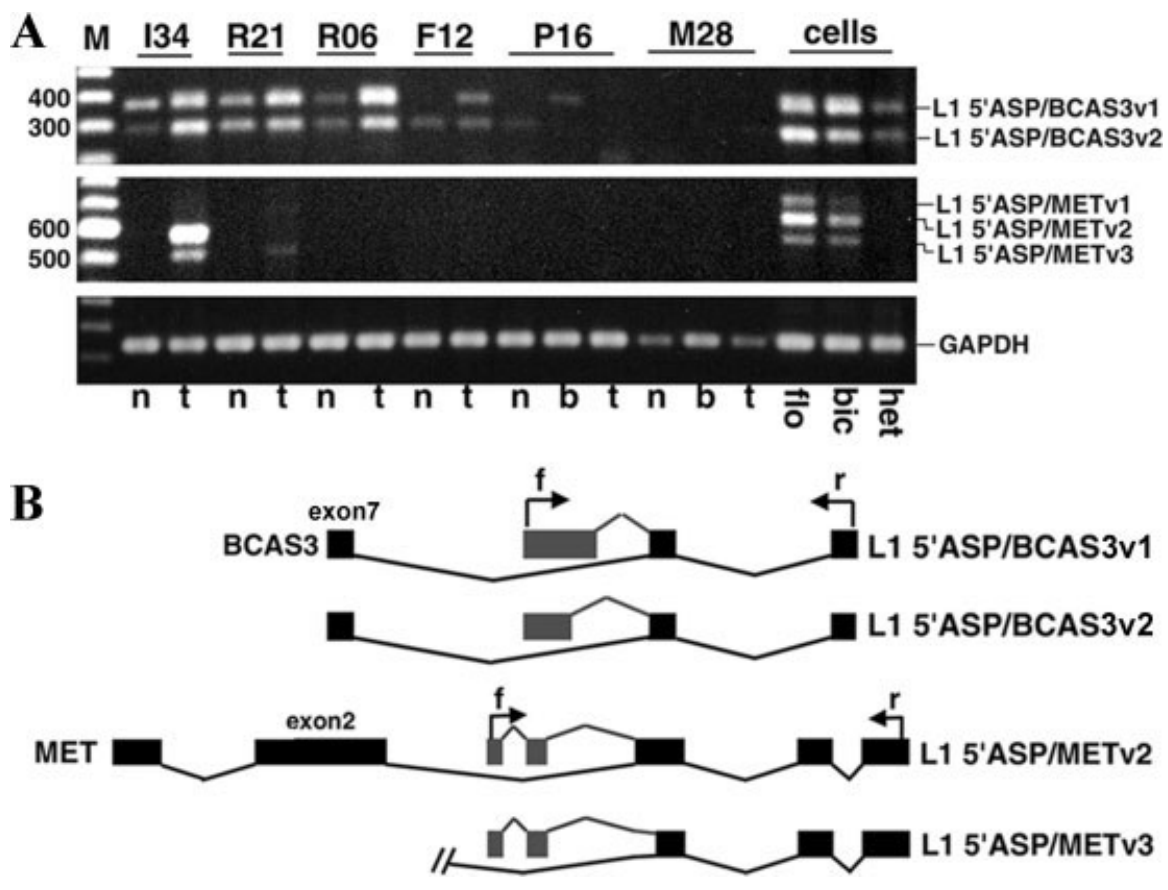

some instability (CIN) (Jallepalli and Lengauer, 2001). Our data from CGH and STS-amplification mapping demonstrated that intrachromosomal amplification occurs at 3q26.3-q27 (Figs. 2A, 3A, 3C, $3 \mathrm{D}$, and 4), and aneuploidy of chromosome 3 was excluded (Fig. 3G). Intrachromosomal amplification may arise from the breakage-fusion-bridge (BFB) cycle (Coquelle et al., 1997). In contrast, CIN appears to involve gross chromosomal changes that lead to aneuploidy in cancers and has been demonstrated to be affected by multiple genes related to cell mitosis (Jallepalli and Lengauer, 2001).

Among the seven ESTs amplified and overexpressed at the 3q26.3-q27 amplicon in EAs, EST $A W 513672$ is a $3^{\prime}$ sequence of cDNA clone AF279780, which originally was cloned from a cDNA library made from an N'Tera2D1 teratocarcinoma cell line that actively expresses full-length L1 RNA (Speek, 2001). L1s are the most abundant mobile elements in the human genome, and their retrotransposition has been associated with genomic instability in transformed cell lines (Ostertag and Kazazian, 2001; Gilbert et al., 2002; Symer et al., 2002). Our data indicate that L1-5'ASP-originated cellular transcripts are not peculiar to cultured cells, for example, in EA cell lines as shown in the present study, but also are present in a subset of primary EAs. We hypothesize that epigenetic changes (i.e., possibly hypomethylation and/or histone acetylation) that occur during EA progres- sion may lead to derepression of the L1-5' ASP. Hypomethylation of the L1 5'U'TR and derepression of $\mathrm{L} 1$ expression have been reported in a variety of human malignant cells as well as in primary cancers (Alves et al., 1996; Chalitchagorn et al., 2004). Consistent with this notion, we identified nine $\mathrm{CpG}$ islands in this L $1-5^{\prime} \mathrm{ASP}$. We also demonstrated that two other $\mathrm{L} 1-5^{\prime} \mathrm{ASP} /$ cellular transcripts within known amplified regions, the L1-5'ASP/MET oncogene and the L $1-5^{\prime} \mathrm{ASP} / B C A S 3$, were found to be differentially expressed in EAs. These findings suggest that derepression of L1-5' ASP may occur at a broad level in the EA genome and could possibly play a role in EA development. However, the relationship between genomic amplification and L15'ASP derepression merits further investigation.

In the present study, we examined specific genetic alterations between EA and the corresponding normal squamous epithelia. Barrett's specimens also were compared with paired normal and tumor samples for genetic alterations in EA development. We and others have provided molecular evidence that Barrett's dysplasia, although premalignant, may lead to EA by direct clonal expansion (this study and Barrett et al., 1999). In addition, our results have demonstrated that sequential alterations of sporadic MSI and genomic amplification occur during EA development. A chimeric L15'ASP/cellular transcript also was differentially expressed within this amplified-core region in a subset of EAs. All three distinct alterations oc- 
curred concurrently within a $2-\mathrm{Mb}$ region of chromosome band $3 \mathrm{q} 26.3-\mathrm{q} 27$ in EA.

\section{ACKNOWLEDGMENTS}

We thank Drs. Donna Albertson and Rick Segraves from the University of California San Francisco for their generous assistance in array $\mathrm{CGH}$ assays. We thank Anne Casper for help in preparing metaphase slides.

\section{REFERENCES}

Ahrendt SA, Decker PA, Doffek K, Wang B, Xu L, Demeure MJ, Jen J, Sidransky D. 2000. Microsatellite instability at selected tetranucleotide repeats is associated with p53 mutations in non-small cell lung cancer. Cancer Res 60:2488-2491.

Alves G, Tatro A, Fanning T. 1996. Differential methylation of human LINE-1 retrotransposons in malignant cells. Gene 176:39-44.

Barlund M, Monni O, Weaver JD, Kauraniemi P, Sauter G, Heiskanen M, Kallioniemi OP, Kallioniemi A. 2002. Cloning of BCAS3 $(17 q 23)$ and BCAS4 (20q13) genes that undergo amplification, overexpression, and fusion in breast cancer. Genes Chromosomes Cancer 35:311-317.

Barrett MT, Sanchez CA, Galipeau PC, Neshat K, Emond M, Reid BJ. 1996. Allelic loss of 9p21 and mutation of the CDKN2/p16 gene develop as early lesions during neoplastic progression in Barrett's esophagus. Oncogene 13:1867-1873.

Barrett MT, Sanchez CA, Prevo LJ, Wong DJ, Galipeau PC, Paulson TG, Rabinovitch PS, Reid BJ. 1999. Evolution of neoplastic cell lineages in Barrett oesophagus. Nat Genet 22:106-109.

Bishop JM. 1987. The molecular genetics of cancer. Science 235:305-311.

Blin N, Stafford DW. 1976. A general method for isolation of high molecular weight DNA from eukaryotes. Nucleic Acids Res 3:2303-2308.

Boland CR, Thibodeau SN, Hamilton SR, Sidransky D, Eshleman JR, Burt RW, Meltzer SJ, Rodriguez-Bigas MA, Fodde R, Ranzani GN, Srivastava S. 1998. A National Cancer Institute Workshop on Microsatellite Instability for cancer detection and familial predisposition: development of international criteria for the determination of microsatellite instability in colorectal cancer. Cancer Res 58:5248-5257.

Bollschweiler E, Wolfgarten E, Gutschow C, Hölscher AH. 2001 Demographic variations in the rising incidence of esophageal adenocarcinoma in white males. Cancer 92:549-555.

Casson AG, Mukhopadhyay T, Cleary KR, Ro JY, Levin B, Roth JA. 1991. p53 gene mutations in Barrett's epithelium and esophageal cancer. Cancer Res 51:4495-4499.

Catto JW, Azzouzi AR, Amira N, Rehman I, Feeley KM, Cross SS, Fromont G, Sibony M, Hamdy FC, Cussenot O, Meuth M. 2003. Distinct patterns of microsatellite instability are seen in tumours of the urinary tract. Oncogene 22:8699-8706.

Chalitchagorn K, Shuangshoti S, Hourpai N, Kongruttanachok N, Tangkijvanich $\mathrm{P}$, Thong-ngam $\mathrm{D}$, Voravud N, Sriuranpong V, Mutirangura A. 2004. Distinctive pattern of LINE-1 methylation level in normal tissues and the association with carcinogenesis. Oncogene 23:8841-8846.

Coquelle A, Pipiras E, Toledo F, Buttin G, Debatisse M. 1997. Expression of fragile sites triggers intrachromosomal mammalian gene amplification and sets boundaries to early amplicons. Cell 89:215-225.

Danaee H, Nelson HH, Karagas MR, Schned AR, Ashok TD, Hirao T, Perry AE, Kelsey KT. 2002. Microsatellite instability at tetranucleotide repeats in skin and bladder cancer. Oncogene 21:4894-4899.

Devesa SS, Blot WJ, Fraumeni JF. 1998. Changing patterns in the incidence of esophageal and gastric carcinoma in the United States. Cancer 83:2049-2053.

Farrow DC, Vaughan TL. 1996. Determinants of survival following the diagnosis of esophageal adenocarcinoma (United States). Cancer Causes Control 7:322-327.

Gilbert N, Lutz-Prigge S, Moran JV. 2002. Genomic deletions created upon LINE-1 retrotransposition. Cell 110:315-325.
Giordano TJ, Shedden KA, Schwartz DR, Kuick R, Taylor JM, Lee N, Misek DE, Greenson JK, Kardia SL, Beer DG, Rennert G, Cho KR, Gruber SB, Fearon ER, Hanash S. 2001. Organ-specific molecular classification of primary lung, colon, and ovarian adenocarcinomas using gene expression profiles. Am J Pathol 159:12311238

Guan XY, Sham JS, Tang TC, Fang Y, Huo KK, Yang JM. 2001. Isolation of a novel candidate oncogene within a frequently amplified region at 3q26 in ovarian cancer. Cancer Res 61:3806-3809.

Heselmeyer-Haddad K, Janz V, Castle PE, Chaudhri N, White N, Wilber K, Morrison LE, Auer G, Burroughs FH, Sherman ME, Ried T. 2003. Detection of genomic amplification of the human telomerase gene (TERC) in cytologic specimens as a genetic test for the diagnosis of cervical dysplasia. Am J Pathol 163:14051416 .

Hughes SJ, Glover TW, Zhu XX, Kuick R, Thoraval D, Orringer MB, Beer DG, Hanash S. 1998. A novel amplicon at 8p22-23 results in overexpression of cathepsin B in esophageal adenocarcinoma. Proc Natl Acad Sci USA 95:12410-12415.

Imoto I, Pimkhaokham A, Fukuda Y, Yang ZQ, Shimada Y, Nomura N, Hirai H, Imamura M, Inazawa J. 2001. SNO is a probable target for gene amplification at 3 q26 in squamous-cell carcinomas of the esophagus. Biochem Biophys Res Commun 286:559-565.

Jackson AL, Chen R, Loeb LA. 1998. Induction of microsatellite instability by oxidative DNA damage. Proc Natl Acad Sci USA 95:12468-12473.

Jallepalli PV, Lengauer C. 2001. Chromosome segregation and cancer: cutting through the mystery. Nat Rev Cancer 1:109-117.

Knuutila S, Bjorkqvist AM, Autio K, Tarkkanen M, Wolf M, Monni O, Szymanska J, Larramendy ML, Tapper J, Pere H, El-Rifai W, Hemmer S, Wasenius VM, Vidgren V, Zhu Y. 1998. DNA copy number amplifications in human neoplasms: review of comparative genomic hybridization studies. Am J Pathol 152:1107-1123.

Kononen J, Bubendorf L, Kallioniemi A, Barlund M, Schraml P, Leighton S, Torhorst J, Mihatsch MJ, Sauter G, Kallioniemi OP. 1998. Tissue microarrays for high-throughput molecular profiling of tumor specimens. Nat Med 4:844-847.

Kuick R, Asakawa J, Neel JV, Satoh C, Hanash SM. 1995. High yield of restriction fragment length polymorphisms in two-dimensional separations of human genomic DNA. Genomics 25:345-353.

Kulke MH, Thakore KS, Thomas G, Wang H, Loda M, Eng C, Odze RD. 2001. Microsatellite instability and hMLH1/hMSH2 expression in Barrett esophagus-associated adenocarcinoma. Cancer 91:1451-1457.

Lagergren J, Bergstrom R, Lindgren A, Nyren O. 1999. Symptomatic gastroesophageal reflux as a risk factor for esophageal adenocarcinoma. N Engl J Med 340:825-831.

Lander ES. 1996. The new genomics: global views of biology. Science 274:536-539.

Lin L, Aggarwal S, Glover TW, Orringer MB, Hanash S, Beer DG. 2000 a. A minimal critical region of the 8 p22-23 amplicon in esophageal adenocarcinomas defined using sequence tagged siteamplification mapping and quantitative polymerase chain reaction includes the GATA-4 gene. Cancer Res 60:1341-1347.

Lin L, Prescott MS, Zhu Z, Singh P, Chun SY, Kuick RD, Hanash SM, Orringer MB, Glover TW, Beer DG. 2000b. Identification and characterization of a $19 \mathrm{q} 12$ amplicon in esophageal adenocarcinomas reveals cyclin $\mathrm{E}$ as the best candidate gene for this amplicon. Cancer Res 60:7021-7027.

Lin L, Miller CT, Contreras JI, Prescott MS, Dagenais SL, Wu R, Yee J, Orringer MB, Misek DE, Hanash SM, Glover TW, Beer DG. 2002. The hepatocyte nuclear factor 3 alpha gene, HNF3alpha (FOXA1), on chromosome band $14 \mathrm{q} 13$ is amplified and overexpressed in esophageal and lung adenocarcinomas. Cancer Res 62:5273-5279.

Ma YY, Wei SJ, Lin YC, Lung JC, Chang TC, Whang-Peng J, Liu JM, Yang DM, Yang WK, Shen CY. 2000. PIK3CA as an oncogene in cervical cancer. Oncogene 19:2739-2744.

Miller CT, Aggarwal S, Lin TK, Dagenais SL, Contreras JI, Orringer MB, Glover TW, Beer DG, Lin L. 2003a. Amplification and overexpression of the dual-specificity tyrosine-(Y)-phosphorylation regulated kinase 2 (DYRK2) gene in esophageal and lung adenocarcinomas. Cancer Res 63:4136-4143.

Miller CT, Moy JR, Lin L, Schipper M, Normolle D, Brenner DE, Iannettoni MD, Orringer MB, Beer DG. 2003b. Gene amplification in esophageal adenocarcinomas and Barrett's with high-grade dysplasia. Clin Cancer Res 9:4819-4825.

Muzeau F, Flejou JF, Belghiti J, Thomas G, Hamelin R. 1997. Infrequent microsatellite instability in oesophageal cancers. Br J Cancer 75:1336-1339. 
Ostertag EM, Kazazian HH Jr. 2001. Biology of mammalian L1 retrotransposons. Annu Rev Genet 35:501-538.

Pinkel D, Segraves R, Sudar D, Clark S, Poole I, Kowbel D, Collins C, Kuo WL, Chen C, Zhai Y, Dairkee SH, Ljung BM, Gray JW, Albertson DG. 1998. High resolution analysis of DNA copy number variation using comparative genomic hybridization to microarrays. Nat Genet 20:207-211.

Redon R, Hussenet T, Bour G, Caulee K, Jost B, Muller D, Abecassis J, du Manoir S. 2002. Amplicon mapping and transcriptional analysis pinpoint cyclin $\mathrm{L}$ as a candidate oncogene in head and neck cancer. Cancer Res 62:6211-6217.

Riegman PH, Vissers KJ, Alers JC, Geelen E, Hop WC, Tilanus HW, van Dekken H. 2001. Genomic alterations in malignant transformation of Barrett's esophagus. Cancer Res 61:3164-3170.

Sia EA, Kokoska RJ, Dominska M, Greenwell P, Petes TD. 1997. Microsatellite instability in yeast: dependence on repeat unit size and DNA mismatch repair genes. Mol Cell Biol 17:28512858.

Singh B, Gogineni SK, Sacks PG, Shaha AR, Shah JP, Stoffel A, Rao PH. 2001. Molecular cytogenetic characterization of head and neck squamous cell carcinoma and refinement of $3 \mathrm{q}$ amplification. Cancer Res 61:4506-4513.
Slebos RJ, Oh DS, Umbach DM, Taylor JA. 2002. Mutations in tetranucleotide repeats following DNA damage depend on repeat sequence and carcinogenic agent. Cancer Res 62:6052-6060.

Speek M. 2001. Antisense promoter of human L1 retrotransposon drives transcription of adjacent cellular genes. Mol Cell Biol 21:1973-1985.

Strand M, Prolla TA, Liskay RM, Petes TD. 1993. Destabilization of tracts of simple repetitive DNA in yeast by mutations affecting DNA mismatch repair. Nature 365:274-276.

Symer DE, Connelly C, Szak ST, Caputo EM, Cost GJ, Parmigiani G, Boeke JD. 2002. Human L1 retrotransposition is associated with genetic instability in vivo. Cell 110:327-338.

Winters C Jr, Spurling TJ, Chobanian SJ, Curtis DJ, Esposito RL, Hacker JF 3rd, Johnson DA, Cruess DF, Cotelingam JD, Gurney MS, Cattau EL Jr. 1987. A prevalent, occult complication of gastroesophageal reflux disease. Gastroenterology 92:118-124.

Yin J, Kong D, Wang S, Zou TT, Souza RF, Smolinski KN, Lynch PM, Hamilton SR, Sugimura H, Powell SM, Young J, Abraham JM, Meltzer SJ. 1997. Mutation of hMSH3 and hMSH6 mismatch repair genes in genetically unstable human colorectal and gastric carcinomas. Human Mutation 10:474-478. 